\title{
SPECTACLES OF SHAME: RYAN MURPHY AS CURATOR OF QUEER CULTURAL MEMORY
}

ABSTRACT. In the anthology Queer Shame, edited by David M. Halperin and Valerie Traub, "the personal and the social shame attached to eroticism" is taken to task in relation to the larger contemporary discourse surrounding gay pride (understood in terms of activism and cultural production), while being seen as a defining characteristic of queer history, culture and identity. Shame, as theorized by Eve Kosofsky Sedgwick, Halperin and others, is predicated on a larger issue of queer people's access to discursive power, which Sedgwick herself had theorized in The Epistemology of the Closet. Such a conceptualizing of queer culture and queer politics begs the interrogation of how queer shame is contained and negotiated in contemporary popular culture.

One of the most successful auteurs working in film and television today, Ryan Murphy's opus is marked by a constant dialogue with queer cultural artifacts. The excitement that his productions generate is typically predicated on his use of queer cultural objects, especially as they are rearticulated for mainstream audiences. This paper investigates the inherent shame of queer memory as embodied in Murphy's show American Horror Story through reference and negotiation of queer icons, filmic traditions and on-screen bodies. Utilizing queer and film theory as its framework, this paper treats Murphy's queer vernacular as the uncanny that destabilizes conventions of both the horror genre and mainstream television, in turn legitimizing and exploiting "shameful" queer categories such as trauma, excess, diva worship and camp through the language of popular television and the bodies that populate it. Finally, this essay evaluates the productive power of Murphy's

mr.stepic@gmail.com

This paper was submitted on July 5, 2017 and accepted for publication at the meeting of the Editorial Board held on September 19, 2017. 
repository of "disgraceful" bodily images-allegorical and literal-in furthering a critical remediation of the vernacular of queer shame.

KEYWORDS: American Horror Story, camp, diva worship, horror, Lady Gaga, Marlene Dietrich, popular culture, queer memory, queer shame, Ryan Murphy, television, the uncanny.

\section{INTRODUCTION}

In Gay Shame, an anthology that emerged from a conference of the same name held in 2003 at the University of Michigan, editors David M. Halperin and Valerie Traub tackle the notion of "the personal and the social shame attached to same-sex eroticism" (Halperin and Traub, 2009, p. 3). They situate the problem of shame within, and in opposition to, the contemporary discourse surrounding gay pride, which they loosely define as "a broad social movement for sexual freedom" (3). While shame has become a sensation due for erasure in the sociocultural context of Pride, the anthology attempts to excavate shame from contemporary discourse by positing it as a defining characteristic of queer history, culture and identity formation.

In her contribution to the anthology, Eve Kosofsky Sedgwick engages with Henry James' The Art of the Novel: Critical Prefaces, and specifically James' therapeutic revisions of his prefaces that would help him come to terms with his younger self, "cathecting or eroticizing that very shame as a way of coming into loving relation to queer or 'compromising' youth" (Sedgwick, 2009, p. 54). Sedgwick characterizes James' relationship with his younger self as a strategy of "dramatizing and integrating shame, in the sense of rendering [it] narratively, emotionally, and performatively productive" (57). Such a return to the scene of the crime, where a queer identity begins to emerge and is infused with feelings of shame, the return to a younger self being "by definition homoerotic" (Sedgwick, 2009, p. 57), may also be read as paradigmatic vis-à-vis the circulation and (re)emergence of historic queer texts, artifacts and bodies in contemporary culture.

This paper takes as its object of study the work of televisual auteur Ryan Murphy. While intermittently referring to other works from Murphy's large opus, the essay primarily engages with the show American Horror Story in order to analyze the representations of "shameful" queer memory and culture in works otherwise 
marketed to a mainstream televisual audience. Premiering in 2011, American Horror Story is an anthology show, with six season airing to date - each a self-contained mini-series, with recurring cast members playing different characters in different settings. The first season, titled Murder House, follows the plights of a family living in a haunted house in Los Angeles. Asylum is set in a 1960s mental institution, terrorized by supernatural forces, unethical medical and religious authorities, and a serial killer. Coven centers around a conflict between two collectives of witches in contemporary New Orleans. Freak Show follows a group of biological rarities in a 1950s travelling circus. Hotel is set in a contemporary Los Angeles hotel run by vampires. Finally, Roanoke capitalizes on the legends surrounding the Lost Colony in a contemporary ghost tale.

In his book Making Things Perfectly Queer: Interpreting Mass Culture, Alexander Doty contributes to the field of reception theory by proposing '"queerness' as a mass culture reception practice that is shared by all sorts of people in varying degrees of consistency and intensity" (2). He posits that,

Queer positions, queer readings, and queer pleasures are part of a reception space that stands simultaneously beside and within that created by heterosexual and straight positions. These positions, readings, and pleasures also suggest that what happens in cultural reception goes beyond the traditional opposition of homo and hetero, as queer reception is often a place beyond the audience's conscious "real-life" definition of their sexual identities and cultural positions - often, but not always, beyond such sexual identities and identity politics, that is. (Doty, 1993, p. 15)

This negotiation of on-screen bodies, whether explicitly queer or so coded, and the spectator's possible queer readings of the text, form the backbone of this paper's argument. Involved on all levels of production as a creator, writer, producer and director on his shows, Murphy belongs to the tradition of auteurs, defined by film theorist Susan Hayward as referring to either "a director's discernible style through mise-en-scène or to film-making practices where the director's signature was as much in evidence on the script/ scenario as it was on the film product itself" (Hayward, 2001, 21). Murphy is well-known for both his distinct style which repeatedly engages in queer vernacular, and for working on explicitly queer projects, such as adapting and directing Augusten Burroughs' Running with Scissors (2006) for the big screen and directing the televisual adaptation of Larry Kramer's The Normal Heart (2014) for 
HBO. Moreover, his work for television repeatedly engages with and advocates contemporary queer issues, most overtly in Glee and The New Normal. Marked by a constant dialogue with filmic, artistic and historic culture that has traditionally been understood or appropriated as queer, the excitement that a Ryan Murphy production generates is typically predicated on his use of queer cultural objects, especially as they are re-negotiated in works aimed at a larger, mainstream audience.

This paper combines queer theory rooted in star studies and celebrity culture on the one hand, and the horror genre on the other, in order to investigate Murphy's mobilization of queer memory, specifically as it figures into shame as a notion constitutive of, and embodied in, queer identities. The assumption is that shame is not only central to the formation of queer taste and memory, but also that Murphy's usage of horror tropes triggers both pleasure and repulsion as they emerge from these cultural references, in turn figuring into the shows' queer sensibility. The use of the term "queer" in this paper aligns with that of Sedgwick's in her article on Henry James. In her theorization of shame, she writes:

I'd venture that queerness in this sense has, at this historical moment, some definitionally very significant overlap, though a vibrantly elastic and temporally convoluted one, with the complex of attributes today condensed as adult or adolescent "gayness." (Sedgwick, 2009, p. 60)

For the purposes of this paper, I will allow myself the elasticity of the term that Sedgwick herself allows, locating queerness in what can be described as Murphy's loose gestures towards "gay" memory and cultural production, while remaining conscious of the fact that the very term is far from exhaustive, instead necessarily intersecting with the politics and questions of, most notably, other gender and sexual identities.

\section{DISARTICULATING CELEBRITY}

In his piece, "Shame on Me, or The Naked Truth About Me and Marlene Dietrich," David Caron recounts his childhood idolatry of Dietrich as both affirmative and shameful during his period of sexual and gender formation. Caron argues that, in terms of gender 
and sexuality, "queer lives are a matter of troping," or "[obeying and disobeying] the injunction in one single move - to be someone else, all right, but the wrong person" (118). The idea of "troping" is at the center of Murphy's work, populated as it is by stock characters and popular archetypes. From the high school setting of Glee, with its roots in American musical theater and youth culture, to American Horror Story, with its wealth of references to classic cinema, horror and otherwise, to Feud, which dramatizes the conflict between Bette Davis and Joan Crawford on the set of What Ever Happened to Baby Jane? and beyond, Murphy introduces the "wrong people" - silver screen idols of the 1950s and pop music sirens, from Marlene Dietrich and Olivia de Havilland, to Madonna and Olivia Newton-John. These references do not always come out of the narrative naturally, but rather feel curated and knowingly inserted as references, and range from allusions for those "in the know" to outright didacticism where the joke is announced and promptly explained. For example, Billie Catherine Lourd plays a character on Scream Queens who repeatedly wears ear muffs in a subtle nod to her real-life mother Carrie Fisher's hairstyle as Princess Leia in the Star Wars franchise; on the other hand, Olivia Newton-John herself appears on Glee and refers to herself as, "Olivia Newton-John, star of Grease, the most successful movie musical of all time" (Brennan, "Bad Reputation"). By constructing narratives around these queer cultural icons, Murphy and his collaborators (most frequently, Ian Brennan and Brad Falchuk) position themselves as announcers and curators of queer memory, with the shows balancing their mainstream status on the one hand, and inherent "gayness" on the other. As Caron suggests in his deconstruction of Dietrich, queerness emerges in Ryan Murphy's works as both empowering and deeply unsettling.

Caron argues that photographs of Dietrich emphasize artifice, distancing the spectator from the notion of authenticity. She is effectively a construct, yet Caron wonders, "Could the staunchest devotion survive the ghastly spectacle of truth?" (123) With this question, Caron offers a point of entry into the problematic of gay shame - as much as gay lives have traditionally been built with secrecy, lies and illusion as frequent parameters, the truth remains the most socially objectionable thing, as the truth of the matter is one's sexuality. Favoring illusion and a plurality of meanings thus becomes a practice of resisting heterocentrism, a kind of queer labor Murphy and his collaborators indulge in by saturating stand- 
ard televisual fare (melodrama, teen comedy, horror) with camp aesthetics. As Fabio Cleto explains in his introduction to the anthology Camp: Queer Aesthetics and the Performing Subject,

Representational excess, heterogeneity, and gratuitousness of reference, in constituting a major raison d'être of camp's fun and exclusiveness, both signal and contribute to an overall resistance to definition, drawing the contours of an aesthetic of (critical) failure: [...] it challenges the cultural imperatives that rely on the manageability of discreet (distinct and docile) historical and aesthetic categories. (Cleto, 1999, p. 3, emphasis in original)

As Cleto's passage suggests, there exists a strong connection between camp and queer shame. It is not merely that camp holds the potential to challenge cultural norms; its propensity to outline "an aesthetic of failure" is directly linked to the aestheticization of spectacle for the purposes of self-fashioning that Caron outlines in his chapter on Marlene Dietrich. Such a connection between homosexuality and camp is duly noted in Susan Sontag's seminal "Notes on "Camp,"' originally published in 1964, where she writes, "Homosexuals have pinned their integration into society on promoting the aesthetic sense. Camp is a solvent of morality. It neutralizes moral indignation, sponsors playfulness" (64). That the homosexual aesthetic as a mode of living is predicated on a sense of taste, on the false distinction between "high" and "low" culture, or esteem and shame, is not lost on Sontag:

The experiences of Camp are based on the great discovery that the sensibility of high culture has no monopoly on refinement. Camp asserts that good taste is not simply good taste; that there exists, indeed, a good taste of bad taste. (Sontag, 1999, p. 65)

As quoted by Christopher Castiglia and Christopher Reed in their deconstruction of the television show Will \& Grace as a text about identity and queer community-formation, Stuart Hall defines identity as "the names we give to the different ways we are positioned by, and position ourselves in, the narratives of the past" (Castiglia and Reed, 2003, p. 158). Thus, shame, queer culture and queer identity are inextricably linked, as identity is not only a matter of cultural history, but also of taste. The aura of low culture, of camp as legitimized bad taste, still pervades queer culture and denotes its icons, legends and stars as somehow inherently shameful, precisely because shared culture becomes the locus of the marginalized, shamed identity. It is in this context that Ryan Murphy's shows 
operate, producing affective pleasure by simultaneously unearthing and legitimizing queer cultural memory, and deconstructing and cannibalizing it.

The artifice of Marlene Dietrich is her appeal; in a queer gesture, she forgoes a claim to authenticity by embracing the construct of the public persona. Thus, when in American Horror Story: Freak Show Murphy introduces Jessica Lange as Elsa Mars, musical performer and the manager of a dying freak show and an obvious riff on Dietrich herself, from her costumes to her accent, he undermines an obvious love letter to the German actress in two important ways. To begin with, Lange camps it up, underscoring the idea that Elsa is down on her luck, a wannabe actress who indiscriminately sleeps around and drinks, the latter mirroring Caron's affection for Dietrich as an exercise in artifice, "knowing that [Dietrich] was completely plastered and that her face was pulled up by safety pins tucked under the wig" (Caron, 2009, p. 123). In other words, Lange plays Dietrich as her opposite, a grotesque doppelgänger to a figure noted for her composure and beauty. Caron's ghastly image of Dietrich's face kept in place by safety pins only works to highlight the artifice; in Murphy, this reoccurs at the end of an episode, when, to the surprise of the viewer, Elsa removes her legs before going to bed, revealing that she is an amputee. Her disability offsets Lange's campy performance in a truly touching moment, which emphasizes stars as constructs, masters of deceit. By having a camp icon in her own right play a "bootleg" version of Dietrich only for her to literally disarticulate herself at the end of the episode, Murphy visually deconstructs the notion of celebrity as it figures in queer cultural memory. The removal of "Marlene Dietrich's" legs reads as a coming out of sorts, an unmasking of the character's (and her fans') carefully constructed artifice that is a strategy for survival as much as it is an exercise in aestheticism.

On the other hand, American Horror Story does not shy away from the spectacle of the male body. In fact, the male body is arguably more sexualized than the women's, as the show features a large number of scenes featuring male nudity, rarely matched on other television programming outside of premium cable networks such as HBO or Showtime. Here, Murphy partakes in a discourse that Richard Dyer dubs "star as a phenomenon of consumption" (Dyer, 1998, p. 17). In his book Stars, Dyer theorizes the appeal of celebrity, and in the context of Hollywood film argues a sexual dimension in the spectators' love for the on-screen stars. Taking up existing 
theorizations of the relationships between spectators and on-screen bodies by Andrew Tudor and Leo Handel, Dyer contends that sexual attraction to celebrity has been marginalized, due to women's traditional status as the main consumers of moving pictures, in which context their sexual attraction to actresses would be considered taboo. However, he maintains for a degree of homosexuality implicit in viewing practices, positing that "cinema has provided through the star phenomenon the vicarious and disguised experience of gay feeling for non-gay audiences" (Dyer, 1998, p. 17).

In his work, Murphy goes a step further and queers this paradigm until the gaze is characterized by a predominant same-sex desire. By repeatedly casting actors to play against type (the type being a wholesome public persona, and the role involving a degree of sexual deviancy), he subverts stars as phenomena of consumption for all audiences and effectively shifts the gaze by exploding the gay/straight binary. For example, teenage heartthrob Nick Jonas plays a gay fraternity student in Scream Queens, and Murphy relishes in framing him sweaty and shirtless in a hypersexualized workout scene set to a bass-heavy soundtrack; later, when the character appears to have been murdered, he is laid out on the slab in nothing but a flimsy pair of underwear, with the camera slowly panning over his muscular body. Evan Peters repeatedly plays a sexual deviant in American Horror Story - his iteration in Freak Show is as a character with webbed hands, which he uses to fist undersexed 1950s housewives for money, while in Murder House he plays a murderous high school student with a penchant for dressing in gimp suits. Murder House also features Dylan McDermott, an actor otherwise known from the formulaic legal drama The Practice, in one of the leading roles. However, American Horror Story finds McDermott repeatedly disrobed, showering and masturbating in scenes of pure spectacle.

With his position as a successful, outspoken and well-connected gay auteur in mind, Murphy's strategies suggest more than just an intention to shock and appall. Rather, by subverting the implied heterocentric male gaze through the spectacle of desire constructed in queer terms, both diegetically and extrafilmically, he invites a homosexual reading that emerges out of an ambivalence of straight/gay representation and the constant repositioning of desire. In doing so, he mirrors Sedgwick's claim in "The Epistemology of the Closet" where, in the context of the homo/heterosexual 
binary, she writes that "contests for discursive power can be specified as competitions for the material or rhetorical leverage required to set the terms of, and to profit in some way from, the operations of such an incoherence of definition" (Sedgwick, 1990, p. 11). Bringing to mind Sedgwick's claims about the contests for discursive power, as well as Dyer's work in star studies, Murphy's interaction with the Hollywood system, which, especially in television, still functions under fairly rigid standards of production, genre and casting, results in work that surprises by inviting an uncannily queer reading that emerges out of the ambivalence of binaries that Sedgwick mentions, such as "masculine/feminine, majority/minority, innocence/initiation" and others (Sedgwick, 1990, p. 11).

\section{THE QUEER UNCANNY}

In his book Queer Temporalities in Gay Male Representation: Tragedy, Normativity, and Futurity, Dustin Bradley Goltz dedicates a chapter to the analysis of the practice of "gay male identities [adopting] the literary frame of tragedy as [the] governing strategy for solidifying heteronormative correctness" (47). The chapter, "Victims in/of Time: Gay Aging as Ritualized Horror," traces representations of gay men in order to argue how "mainstream gay representation [is] a fragmented horror story, a never-ending dance with death that situates gay lives in constant relation to dying, loss, and looming mortality" (Goltz, 2010, p. 49). While representations of gay men as deviant, menacing figures have a long and sordid history, Goltz's chapter unwittingly engages with Sedgwick's concerns over discursive power in its argument that the normalization of violence against gay men allows "dominant audiences [...] to temporarily identify with non-normative sexual desires through a gay character and then redeem themselves and heteronormative perfection through symbolically sacrificing the gay representation" (Goltz, 2010 , p. 50). What emerges as a critical question in the context of Murphy's opus is how this paradigm can be negotiated, considering that Murphy himself employs the same strategy. At the center of not just American Horror Story, but also Glee and The New Normal, are queer characters (or gay projections, like Elsa Mars) that are brutalized, suffering varying degrees of violence, and thus perpetuating the mode of gay representation that Goltz outlines. 
While Murphy's shows are almost didactic in their condemnation of violence the marginalized characters experience, they nevertheless inflict horror on their queer characters and in so doing are complicit in the tradition that Goltz outlines. For example, not one but two seasons of American Horror Story feature horrific versions of conversion therapy, one pseudoscientific in the 1950s setting of Asylum and the other more metaphorical, through a rape of a hermaphrodite in Freak Show. An overwhelming problem with Murphy is that his unique brew of television, which flirts with the genre conventions of horror, pornography and melodrama - three genres that film theorist Linda Williams claims are marked by excessive spectacle and a cyclical, repetitive nature (Williams 1991, p. 3) - locates sexuality as a site of trauma. Although trauma is arguably a matter of excess (of emotions, for example), and is experimented cyclically, the fact remains that Murphy's work is primarily conceived as entertainment, and as such counts on trau$\mathrm{ma}$, and specifically queer trauma, to frighten and entertain.

As Harry M. Benshoff puts it, "While the notion of the monster queer or sexual outlaw holds a great counter-hegemonic force for social and semantic change, it is concomitantly the same stance which opponents of gay and lesbian civil rights invoke to demonize that cause" (256). Thus, it is difficult for Murphy's "monster queers" to escape their marginalized position, especially since this position is built into the show's project as horrific or uncanny. Rooted in Freud's idea of the unfamiliar, or "the unheimlich," the uncanny is a method of critically approaching a familiar object or discourse by rendering it unfamiliar in order to analyze it from a required distance (Trigg 2012, p. 33). Richard Dyer, writing on representations of homosexuality and horror in The Culture of Queers, posits that "all 'monsters' in some measure represent the hideous and terrifying form that sexual energies take when they 'return' from being socially and culturally oppressed" (Dyer 2002, p. 75). In other words, horror becomes a mode of representing silenced sexuality, simultaneously betraying the silence and pushing for political usefulness. For the purposes of this paper, I will focus on vampirism as a way of narrativizing the vengeful uncanny, as it emerges in American Horror Story: Hotel.

The fifth iteration of American Horror Story, Hotel focuses on a series of supernatural occurrences in a contemporary Los Angeles hotel. At the center of the show is the character of the Countess, played by pop music star Lady Gaga, who early in the proceedings is 
revealed to be a vampire. In a scene from the second episode, titled "Chutes and Ladders" and directed by Bradley Buecker, the Countess turns a young model, Tristan (Finn Wittrock), into a vampire and takes him as a lover. The episode features an extended scene of the two making love, bathing together and lounging while the Countess recounts her preternaturally long life, at which point there is a cut to the interior of New York's famed nightclub Studio 54 sometime in the 1970 s. The countess is seen entering the discotheque on a horse (a reference to Bianca Jagger's similar entrance to her birthday party at Studio 54 in 1977), dancing and drinking blood in a frenzy of disco music and strobe lights. The scene then cuts back to the bedroom in present day, where the Countess is melancholically whispering, "I mourn it still. I think about everything that could have been had they all lived. My friends: Andy, Keith, Robert. All that loss." (Minear, "Chutes and Ladders") Tristan, unaware that the names correspond to artists Andy Warhol, Keith Haring and Robert Mapplethorpe, asks the Countess whether those were her victims.

In this scene, the creators of American Horror Story (and Murphy as the showrunner specifically) assume the role of historians, reimagining the queer history of the 1970 s and 1980s by mobilizing the tropes of the vampire genre. Through the character of the immortal vampire/disco queen, the show ushers in a specifically queer discourse on AIDS, but also disco music and the queer art scene. The strategy is reminiscent of Dyer's comparison of vampirism to homosexuality as similarly suspicious identities:

In most vampire tales, the fact that a character is a vampire is only gradually discovered - it is a secret that has to be found out. The analogy with homosexuality as a secret erotic practice works in two contradictory ways. On the one hand, the point about sexual orientation is that it doesn't 'show', you can't tell who is and who isn't just by looking; but on the other hand, there is also a widespread discourse that there are tell-tale signs that someone 'is'. The vampire myth reproduces this double view in its very structures of suspense. (Dyer, 2002, p. 78)

The "double view" that Dyer speaks of is another example of the ambivalence in the previously discussed heterosexual/homosexual binary as mobilized by the show. This particular scene, however, serves as an example of how Murphy utilizes a standardized and identifiable genre of vampire fiction as a metaphor for the emergence of queer "monsters" in a revenge against media silence about 
not just homosexuality, but also queer art, HIV/AIDS and low culture, all shameful by virtue of being constitutive of the gay identity. The ambivalence of identity is also evident in the Countess referring to Warhol, Haring and Mapplethorpe by their first names, signaling the circulation of queer cultural memory as something that is still marginal, inviting the more astute (queer?) viewers to fill out the gaps in the representation themselves, while the references may go over the head of young Tristan, a stand-in for the segment of the audience uninvested in queer history and culture.

Moreover, the Countess' mourning for the 1970s fits into a larger body of theory on vampire narratives as ones of melancholia and loss. In her analysis of the 1994 film Interview with a Vampire, the big-screen adaptation of Anne Rice's seminal book of the same name and a modern classic of homoeroticism in itself, Maria Yassa argues that vampirism "bears resemblances to grief and melancholia" with its repeated tropes of "concealment, timelessness, inaccessibility, the experience of and wish to be dead like the lost object" (Yassa, 2000, p. 177). Although Yassa's article does not delve into the homoerotic undertones of Interview with the Vampire, her description of the vampiric state speaks volumes of how and why the vampire has traditionally been made into a foil for same-sex desire. The decidedly gloomy qualities Yassa lists are all verbalized by the Countess as a projection of gay identity in Hotel, in turn reminiscent of Jessica Lange's Dietrich-esque Elsa Mars in Freak Show. Concealment, existing outside of one's own time and a closeness to death, not to mention Yassa's suggestion of suicidal tendencies, are all constitutive of the proverbial closet, or the experience of coming into one's own sexuality. Death, specifically, is central to this experience, as Monica B. Pearl has noted, the fear and shame in being gay arising from not only the possibility of death by AIDS, but also "death of innocence, death of heterosexual identity, death of parental/adult authority, death of the natural order" (Pearl, 2013, p. 8). In this light, the inclusion of tropes such as vampirism do not only allow Murphy and his collaborators to pay homage to queer history encoded in narratives that typically feature these tropes, but also serve to cast a different light on mainstream, heterocentric culture itself. By resisting the urge to excessively define much of gay culture present in his work unless it is played as an inside joke, Murphy transforms the queer collective history into the queer uncanny, which in turn aims to appeal to both audiences in a way reminiscent of Benshoff's theorization of 
the "monster queer": "The monster queer may be a sexy, alluring, politically progressive figure to some, while to others [...] $\mathrm{s} / \mathrm{he}$ is still a social threat which must [be] eradicated" (256). With repeated re-emergence of the queer uncanny through a wealth of cultural references, Murphy's shows (and American Horror Story, which simultaneously appropriates and lampoons the traditions of the horror genre, in particular) are marked by an investment in narrative and representational ambiguity, reconstructing familiar narratives using conventions of "excessive" genres, particularly through camp's "representational excess," as Cleto puts it, and presupposing a queer turn towards the past as a dominant model of storytelling.

CONCLUSION In her essay, "The Monstrous House of Gaga," Karen E. Macfarlane unpacks the pop star in terms of her often grotesque visual imagery, arguing that her persona is "inscribed as a kind of alternative form of community," but also "liminal, and the embodiment of cultural anxieties" (Macfarlane 2012, p. 114). On a continuum of queer visual culture that both Marlene Dietrich and Lady Gaga belong to on their respective terms, Gaga's otherness is explained as emerging out of equal rights advocacy, and as such represents a product of trauma (Macfarlane, 2012, p. 114). Macfarlane's account of Lady Gaga's popularity is compelling, particularly when it comes to the singer's status as gay icon. Personal trauma, rooted in feelings of inadequacy, or the inability to negotiate identity binaries, not to mention collective trauma pertaining to systemic political and cultural marginalization of queers, is inscribed in the singer's audiovisual performance, and in turn inextricably connected to shame as the flipside of queer pride/Pride as the political bottom line.

In his text "Why Gay Shame Now?," Halperin asserts that "the only gay pride that is endurable is a gay pride that does not forget its origins in shame" (Halperin 2009, p. 44). Similarly, Ryan Murphy's televisual opus serves as a repository of images, cultural references and vocabulary that remediates the language of shame. Moreover, these vernacular elements, coupled with direction that bears Murphy's stamp either through his role as director or showrunner, form narratives that convey gay shame as a strategy of resistance by employing it as an uncanny vernacular that seeks to complicate the conventions of mainstream media. In his simultaneous exploitation of contemporary forms and queer cultural staples, 
Murphy mirrors Sedgwick's claim that "shame is simply the first, and remains a persistent, structuring fact of identity: one that, as [Henry] James's example suggests, has its own powerfully productive and powerfully social metamorphic possibilities" (Sedgwick 2009 , p. 61). In this light, the queer project that is at the heart of Murphy's work, and American Horror Story especially, is the production of pleasure through an allegorical invocation and sacrifice of the "shameful" horrors of the queer past: its iconic disco queens, fabulous stars of the silver screen and a community that persists in plain sight. sion series episode]. In: Murphy, R. (Executive producer), Glee. USA: Fox.

Caron, D. (2009). Shame on Me, or The Naked Truth About Me and Marlene Dietrich. In: D. M. Halperin and V. Traub (Eds.), Gay Shame (pp. 117-131). Chicago: University of Chicago.

Castiglia, C., \& Reed, C. (2003). “Ah, Yes, I Remember It Well”: Memory and Queer Culture in Will and Grace. Cultural Critique, 56, 158-188. doi: 10.1353/ cul.2003.0057

Cleto, F. (1999). Introduction: Queering the Camp. In: F. Cleto (Ed.), Camp: Queer Aesthetics and the Performing Subject: A Reader (pp. 1-42). Ann Arbor: University of Michigan.

Benshoff, Harry M. (1997). Monsters in the Closet: Homosexuality and Horror Film. Manchester: Manchester University Press.

Doty, A. (1993). Making Things Perfectly Queer: Interpreting Mass Culture. Minneapolis: University of Minnesota.

Dyer, R. (2002). It's in His Kiss!: Vampirism as Homosexuality, Homosexuality as Vampirism. In: The Culture of Queers (pp. 116-136). London: Routledge.

Dyer, R. (1998). Stars. London: BFI.

Goltz, D. B. (2010). Victims In/of Time: Gay Aging as Ritualized Horror. In: Queer Temporalities in Gay Male Representation: Tragedy, Normativity, and Futurity (pp. 47-80). New York: Routledge.

Halperin, D. M. \& Traub V. (2009). Beyond Gay Pride. In: D. M. Halperin and V. Traub (Eds.), Gay Shame (pp. 3-40). Chicago: University of Chicago.

Halperin, D. M. (2009). Why Gay Shame Now?. In: D. M. Halperin and V. Traub (Ed.), Gay Shame (pp. 41-46). Chicago: University of Chicago.

Hayward, S. (2001). Cinema Studies: The Key Concepts (2nd ed.). New York: Routledge. 
Macfarlane, K. E. (2012). The Monstrous House of Gaga. In: J. D. Edwards and A. Soltysik Monnet (Eds.), The Gothic in Contemporary Literature and Popular Culture: Pop Goth (pp. 114-134). New York: Routledge.

Minear, T. (Writer), \& Buecker, B. (Director). (2015) Chutes and Ladders [Television series episode]. In: Murphy, R. (Executive Producer), American Horror Story. USA: FX.

Pearl, Monica B. (2013). AIDS Literature and Gay Identity: The Literature of Loss. New York: Routledge.

Sedgwick, E. K. (1990). Epistemology of the Closet. Los Angeles: University of California.

Sedgwick, E. K. (2009). Shame, Theatricality, and Queer Performativity: Henry James' The Art of the Novel. In: D. M. Halperin and V. Traub (Eds.), Gay Shame (pp. 49-62). Chicago: University of Chicago.

Sontag, S. (1999). Notes on 'Camp'. In: F. Cleto (Ed.), Camp: Queer Aesthetics and the Performing Subject: A Reader (pp. 53-65). Ann Arbor: University of Michigan.

Trigg, D. (2012). The Memory of Place: A Phenomenology of the Uncanny. Athens: Ohio University Press.

Williams, L. (1991). Film Bodies: Gender, Genre, and Excess. Film Quarterly, 44(4), 2-13. doi: $10.2307 / 1212758$

Yassa, M. (2000). Vampirism, Depression and Symbolization: An Analysis of the Film Interview with the Vampire. The Scandinavian Psychoanalytic Review, 23 (2), 174-192. doi: 10.1080/01062301.2000.10592599

НИКОЛА Н. СТЕПИК

УНИВЕРЗИТЕТ КОНКОРДИЈА

ЦЕНТАР ЗА ИНТЕРДИСЦИПЛИНАРНЕ СТУДИЈЕ ДРУШТВА И КУЛТУРЕ

РЕЗИМЕ

ПРИЗОРИ СТИДА: РАЈАН МАРФИ

КАО КУРАТОР КВИР КУЛТУРЕ И МЕМОРИЈЕ

У антологији Квир cūug, уредници Дејвид М. Халперин и Валери Трау $\delta$ пишу о „личном и друштвеном стиду везаном за еротику“ у оквиру савременог контекста геј поноса у доменима активизма и културе, а у исто време и као дефинишуће карактеристике квир историје, културе и идентитета. Према теоријама Ив Кософски Сеџвик, Халперина и других, стид је означен већим питањем дискурзивне моћи и њене доступности квир особама, а то је проблематика којом се Сеџвик позабавила у 
својој књизи Ейистеммолоїuја „ормара“. Овакво разумевање квир културе и политике моли за анализом идеје квир стида у савременој популарној култури.

Опус Рајана Марфија, једног од најуспешнијих филмских и телевизијских твораца данашњице, означен је сталним дијалогом са историјским плодовима квир културе. Популарни одзив који његови пројекти побуђују великим је делом изазван Марфијевом интеракцијом са квир културом, а посебно начин на који је та иста култура реартикулисана за ширу публику. Овај рад приступа стиду као нераздвојивом елементу колективне квир меморије у Марфијевој серији Америчка хорор йрича, где се квир меморија појављује кроз алузије на квир иконе, филмску традицију и тела на екрану да $\delta$ и се даље деконструисала. Кроз квир и филмску теорију, овај есеј третира Марфијев квир визуелни речник као језовите елементе који кроз језик популарне телевизије и с нагласком на телесно дестабилизују конвенције хорор жанра и телевизије, у исто време легитимишући али и експлоатишући „срамне“ категорије квир искуства као што су траума, претераност, љубав ка дивама и кемп. Коначно, овај рад приступа Марфијевој колекцији „срамотних“ телесних приказа, у алегоријском и буквалном смислу, у циљу евалуације посредничког потенцијала ових слика као својеврсног вокабулара квир стида.

КљУчНЕ РЕчИ: Америчка хорор йрича, кемп, дива, хорор, Леди Гага, Марлен Дитрих, популарна култура, квир меморија, квир стид, Рајан Марфи, телевизија, језовито.

Овај чланак је објављен и дистрибуира се под лиценцом Creative Commons Ауторство-Некомерцијално Међународна 4.0 (CC BY-NC 4.0 |

https://creativecommons.org/licenses/by-nc/4.0/).

This paper is published and distributed under the terms and conditions of the Creative Commons Attribution-NonCommercial International 4.0 licence (CC BY-NC 4.0 | https://creativecommons.org/licenses/by-nc/4.0/). 